\title{
The Birth of BBC Radio 4's Analysis
}

\section{Hugh Chignell}

Hugh Chignell (Ph.D., Bournemouth University, 2005) is a Senior Lecturer in the Bournemouth Media School, Bournemouth University, United Kingdom. His research interests include broadcasting history with special reference to radio and radio archives. He is Chair of the (UK) Southern Broadcasting History Group.

BBC Radio 4's 'Analysis' was first broadcast in 1970 and represented a striking departure from the tendency to combine news and comment in radio current affairs. It was created by a small network of broadcasters who believed that current affairs was distinct from radio journalism. The publication of the controversial document 'Broadcasting in the Seventies' in 1969 and the outcry which followed it gave this group their opportunity to produce an elite form of radio.

\section{INTRODUCTION}

This article attempts to answer a series of very specific questions. Why was the flag ship BBC radio current affairs program, Analysis created when it was? What specific interpretation of 'current affairs radio' did it embody and what made its birth possible? And finally, who created it? Drawing mainly on interview evidence and memoirs of former BBC staff it is possible to answer these questions with some precision and to show the broadcasting context (the BBC in the 1960s) in which the conception of Analysis took place.

It is not the intention here to describe the specific nature of the program's account of current affairs or its decidedly right-leaning politics. This is a case study of how two men, George Fischer and Ian McIntyre, saw their opportunity to buck the populist trend in radio and impose their conservative and Reithian broadcasting values in this elitist experiment in current affairs radio.

\section{JOHN REITH'S BBC}

Few national institutions have been more influenced by the character and beliefs of their founder than the BBC. The Presbyterian moralist and authoritarian, John Reith, fashioned the British Broadcasting Company (1922-1926) and then the British 
Broadcasting Corporation (1927 - 1938, when he resigned) largely in his own image. Famously, Reith wanted a public service influenced by the ideals of the great Victorian reformer, Matthew Arnold. The BBC would not just entertain but also educate and inform and in so doing would help incorporate the working class into the social and political order. Much of the programming of the pre-war period was 'uplifting' and worthy. Serious educational talks, plays and classical music together with a great deal of religious programming were presented alongside the more popular diet of light music and comedy. In her recent examination of the BBC in the 1990s, Georgina Born discusses the nature of Reith’s early BBC (Born, 2004). She rightly points out that although culturally elitist and dismissive of the views of the audience, the early corporation provided a wide range of listening experiences which were previously unavailable to the mass of the population.

A mixture of social and cultural changes together with the democratising influence of war inevitably put pressure on the high-mindededness of the BBC. The introduction of the Listener Research Unit in 1936 made the preferences of the audience (as opposed to their perceived 'needs') a greater influence on programming and the departure of Reith in 1938 freed the organisation to experiment and diversify.

The BBC in the 1950s had, to an extent, adapted to the modern world but the forensic analysis of the BBC by the American commentator, Burton Paulu, depicted its news and current affairs programming as conservative, elitist and cautious. Paulu found the $\mathrm{BBC}$ to be a moribund and unprofessional broadcaster and one which he unfavorably compared to Amercian radio. He felt, for example, that the Talks department needed producers who were aware of their audience, ' but most of (Talks Department) producers are high minded scholars rather than showmen'. (Paulu, 1956, p.121.) What was needed were 'audience aware producers' rather than the BBC's socially and educationally privileged producers whose elitism and amateurism hindered their understanding of the audience.

Paulu saw the division of the talks department from news (the origins of which went back to the 1930s) as a source of difficulty, '...nor does the News Division have anything to do with commentaries and interpretations of the news or discussions of current affairs; these are the responsibility of the Department of Talks'. (Paulu, p.157.) 
In particular he highlighted the problems this created for news. The old BBC anxiety about combining news and comment was for Paulu responsible for dull, cold and humourless news, 'like a foreign office communique'.

\section{BBC RADIO IN THE 1960s}

The 1960s was for BBC radio, as it was for British society more generally, a time of radical change. These changes were designed to adapt radio to increased competition from television (since 1955 this included Independent Television, a commercial rival to the BBC) and the changing tastes of the audience. In 1960 the newly created Director General of the BBC, Hugh Greene closed down the current affairs magazine program, At Home and Abroad and the Nine O'clock News (which had been in existence since the 1920s) and created a daily news and current affairs program, Ten o'Clock. This combination of news and comment in one program was widely criticised. Briggs records the complaints made about the fusion of fact and comment including a letter to The Times from the Archbishop of Canterbury (Briggs, 1995). Despite the protests over Ten o'Clock, Greene further consolidated news and current affairs under the Editor of News and Current Affairs in June 1960, a role which he then absorbed into his own as Director General. The anxieties expressed about these changes are important if only because to the modern listener, so used to news and comment in one program, they are difficult to comprehend. The author and critic, Joanna Richardson was particularly critical of the abolition of the Nine O'clock News:

The BBC should keep news and comment absolutely distinct. It should not concede too much to popularity; and it should cater for listeners .. who like to have the news straight, and form their own opinions. (Quoted in Briggs, 1995, p.328).

This concern that news and comment should be kept separate was the orthodox view in the BBC but one that Greene and the senior managers of BBC radio were clearly prepared to challenge. Two men in particular, Frank Gillard and Gerard Mansell, were responsible for radical changes to BBC radio to which Analysis was a reaction.

Frank Gillard was something of a radio visionary. His varied background included a celebrated career as a BBC war correspondent (Miall, 1994), his time spent away 
from the constraints of the BBC in London at West Region (where among other innovations he created Any Questions) and his inspiring encounter with American local radio which made him into an enthusiastic supporter of that cause (Briggs, 1995, p. 620). Gillard was eventually lured away from West Region to become Director of Sound Broadcasting in 1963. He established his credentials as a man of action by abolishing both Children's Hour (1927 - 1964) and the Features Department. As Features had been the home of some of the most innovative and challenging radio, servicing almost exclusively the Third Programme and staffed by some of radio's most famous names (including Laurence Gilliam, Louis McNeice and D.G. Bridson), its abolition was a brave if perhaps unsurprising move.

The other interesting appointment of a 'radical' was Gerard Mansell's promotion to Chief of the Home Service in May 1965. Like Gillard, Mansell had not come from BBC radio’s natural London centre at Broadcasting House but had spent the previous fourteen years at Bush House, the home of External Services. Mansell believed in format radio as a cost effective and practical way of delivering diverse content in the modern, televisual world and by 1970 his ideas had won the day.

Under Gillard's direction, in 1967 the radio networks were reorganised and renamed Radios 1, 2, 3 and 4. Mansell's Radio 4 was emerging as the main place for news and current affairs. He had started down that road with the introduction of The World at One in 1965. Radio 1 had been created as a largely pop music network, Radio 3 had some speech but was mainly classical music and so the move towards format radio had begun.

Gerard Mansell’s Radio 4 (or 'The Home Service' as it was known up to 1967) in the decade before the launch of Analysis broadcast a very wide variety of programs. More than any of the other BBC radio networks it expressed Reith's belief in mixed programming. Increasingly the place to hear news and current affairs, it also continued to feature radio drama, talks on a huge variety of both topical and educational subjects, features and documentaries, religious and educational programs, religion and even sport. On a typical day there would be nine news bulletins, three or four news magazines, plays, a radio ‘soap', at least one documentary, a religious 
service, some live orchestral music and one or more quiz programmes. A belief in the value of 'serendipity' was still held in the BBC and the hope that the listener to Radio 4 in particular might be surprised in to listening to a serious documentary or challenging piece of drama.

Mansell's ambition to both expand news and comment on Radio 4 and make this factual output more digestible to the listener went some way to answer Paulu's criticisms. This process of modernism in BBC radio peaked at the end of the 1960s with the publication of a document perceived by many traditionalists as the BBC's final betrayal of its Reithian heritage.

\section{BROADCASTING IN THE SEVENTIES}

Broadcasting in the Seventies was the culmination of a process of change towards format radio. It was written by Gillard's successor as Managing Director, Radio, Ian Trethowan and published in July 1969. Trethowan's document had a particular impact on Radio 3 which became almost exclusively a music network relying increasingly on records. Almost all speech content on Radio 3 was transferred to Radio 4. Mixed programming would survive only on Radio 4 and the whole policy of format radio, targetting specific audiences with discrete program content was made explicit. It produced a dramatic reaction from the cultural elite. Within weeks the Campaign for Better Broadcasting was launched to fight the changes. In a letter to The Times signed by Sir Adrian Boult, Professor Max Beloff, Jonathan Miller, Henry Moore and others the gravity of the attack was well expressed:

[The BBC's policy] seriously threatens the unique role the BBC has played in the cultural and intellectual life of the country [and would] prove disastrous to the standards and quality of public service broadcasting... the issues involved transcend any individual or group interest and we feel that only by organizing all dissent into a unanimous voice will there be any hope of affecting a fundamental change of heart at the $B B C$ which is proceeding with its plans despite the evidence of public dismay. (Briggs, 1995, p.785). 
The reaction to Broadcasting in the Seventies was partly driven by the concern that the reorganization of radio into generic networks would dilute the quality of output and in particular on Radio 3. This was exacerbated by proposals to reduce the number of BBC orchestras. There was also concern that the traditional Reithian notion of 'mixed programming' was being abandoned. Eventually the outburst against the proposals died down. It probably helped that at the end of the year Frank Gillard retired. Broadcasting in the Seventies was in a sense the culmination of Gillard's radical and arguably populist approach which had influenced the management and direction of radio throughout the 1960s. After Gillard's departure BBC radio regrouped under Ian Trethowan.

\section{THE BIRTH OF ANALYSIS}

By the beginning of January 1970 the mood in BBC radio was one of compromise, as this revealing extract from Briggs shows:

During the spring of 1970 BBC top management had shown itself anxious, above all else, to reduce contention. Trethowan had never liked polarization. Mansell, who became Director of Programmes, Radio, in January 1970, wanted his colleagues to get down to programme making as quickly as possible...(Briggs, 1995, p. 800).

In January the new Controller of Radio 4, Tony Whitby, had arrived in post having been proposed by Trethowan. He appeared to have the right qualities to 'reduce contention'. He is described in Briggs's work as a man who 'combined intelligence, enthusiasm and charm and listened carefully to his critics... perhaps it helped that while at Oxford he had written a thesis on Matthew Arnold: he knew what 'Philistines' were'. (Briggs, 1995, p.800). Whitby’s Radio 4 had now inherited some of the speech programming which had previously existed on Radio 3. If ever there was a time to introduce a cerebral, single subject current affairs program then this was it.

Analysis was created in part to silence the BBC's critics. With the BBC still bruised after the uproar over Broadcasting in the Seventies this was a good time to introduce on Radio 4 a demanding, single subject current affairs program, reminiscent of an in- 
depth Radio 3 documentary. The first presenter of the program, and one of its creators, Ian McIntyre himself takes this view:

What had been going on in the background in the BBC at the time was the changeover from the old format of the Home Service and so on to the networks, to a sort of streaming which they said was to be generic broadcasting... and in all the uproar about this, one cause of concern was what was going to happen to serious current affairs broadcasting. So in a way, the idea for Analysis was that it should be a sort of demonstration of good faith to the listener that there were going to be serious things done. (Personal communication, February 26, 1999)

Analysis, in McIntyre's words, would be 'serious', a demanding listen which would stretch the listener and also feature important people as contributors discussing the main current affairs issues of the day. Analysis was also the result of a decision to move Radio 3 style talks programs from the newly 'formatted' Radio 3 to the more mixed Radio 4. So the 'serious' Analysis with its Radio 3 heritage would signal clearly to the members of the Campaign for Better Broadcasting and their supporters that they were wrong to think that the quality of public service broadcasting had been damaged. The new current affairs program would enshrine the traditional ideas of quality as formulated by Reith.

The four men directly responsible for creating Analysis were Tony Whitby (Controller, Radio 4), Ian McIntyre, an occasional presenter of talks programs on Radio 3, Lord Archie Gordon (Editor, Talks and Documentaries Radio) and the producer, George Fischer. McIntyre had worked on the innovative current affairs program, At Home and Abroad in the 1950s. He had joined the Current Affairs Talks Department in 1957 to work alongside Archie Gordon and Tony Whitby (both important in the early stages of Analysis). He was appointed when John Green was Controller, Talks and is of the opinion that his similarities with Green had played a part in his appointment as he explains in this frank comment:

[Stephen Bonarjee] told me many years later that that [McIntyre's similarities to Green] had been an element in John Green's wanting to appoint me. Because I, like John Green, had been at Cambridge. I, like John Green, had been President of the 
Union at Cambridge. I, like John Green was a Tory. (Personal communication, February 26, 1999)

McIntyre not only shared with Green a social background, but also a Reithian conservatism about current affairs broadcasting. Green represented traditional elitist or anti-populist BBC views, including concern about the combination of news and comment in magazine formats. Like Green, McIntyre was not only a broadcasting conservative. After a short career as a member of BBC staff, McIntyre spent most of the 1960s on the staff of the Conservative Party in Scotland and was an unsuccessful Conservative parliamentary candidate in 1966. From the 1950s, he had presented occasional talks and documentaries for the Third Programme. It was this freelance work which helped build the informal alliances which then spawned Analysis.

This informal network extended further than this immediate group of four. It also included Howard Newby, Controller Radio 3 who went on at the end of 1971 to become Director of Programmes, Radio and Ian Trethowan, Managing Director, Radio (Carpenter, 1996, p.298). McIntyre saw this group as a support network for the new current affairs program:

... it was a marvellous situation, because here was George [Fischer], who was a good friend, here was Tony [Whitby] , he was a good friend, here was Howard Newby who was a good friend and old colleague ... and here was Trethowan, so it was a tremendous stack. I mean that was real protection for the programme ... (Personal communication, February 26, 1996)

The importance of informal networks in the BBC is one of the themes in Tom Burns exploration of the public and private aspects of the corporation (Burns, 1977). He was struck by the presence of a 'BBC type' especially among talks producers, exactly the type so lambasted by Paulu. They combined 'intelligence, assurance, receptivity, and social deftness ... the special code of manners and style of behaviour, speech and demeanour..' (p. 99). Burns describes the formation of 'acquaintanceship networks' developing in the BBC as people moved up the hierarchy. Those at the top shared 
allegiance to a ' moral order' and a commitment to change which would keep their values alive in the $\mathrm{BBC}$ :

... their own sense of the fitness of BBC things had brought them to the top. The moral order permeated all network and all levels, but people at the top were, by definition, especially conscious of it, felt responsible for maintaining it, and, if need be, trying to correct or reorient it. (Burns, 1977, p. 84)

These ‘BBC types’ often shared a similar educational background. Ian Trethowan’s autobiography contains some useful further clues on the way friendship, and the ties created by working together, impacts on future careers (Trethowan, 1984). He describes Tony Whitby, alongside whom he worked on the television series Gallery, in glowing terms, 'we formed an admirable working partnership' and 'only later did I realize how fortunate I was to have as my first editor in the BBC someone as balanced and mature as Tony Whitby.' (p. 105) A few years later Trethowan was responsible for the appointment of Whitby as Controller, Radio 4. Trethowan also comments on his own appointment as Managing Director, Radio, 'at the personal level, both Charles Hill [Chairman of the BBC] and Charles Curran [Director General] simply liked the idea of my being around.' (p.122) Central to Burns' discussion was what he perceived as the burgeoning professionalism of the BBC at the time. Paulu had chastised the organisation for its amateurishness but Burns saw the beginnings of professionalism from the early 1960s. Despite this, the candid reflections of men like Trethowan and McIntyre cited here, suggesting a system of preferment made on the basis of social compatiblity, familiarity and friendship, challenge that professional image.

Another factor in the creation of Analysis was the reaction to the huge growth in journalistic or news-based current affairs, especially in Mansell's Home service and Radio 4. Ian McIntyre, the first presenter of Analysis, supported the traditional BBC distinction between news and current affairs to the extent that he defined himself as not a journalist.

Journalists were people who worked for newspapers, and there were some people who had come from newspapers and worked in the BBC's News Division, and they 
called themselves journalists, some of them, but we did not regard ourselves as journalists, we regarded ourselves as current affairs broadcasters, and it was a very different sort of animal really. The business of journalists was to get the news and present it. Our business was to get behind the news, and dig and illuminate and go a bit further, and they were very, very distinct disciplines, we thought. News didn't agree, and were resentful that we made the distinction, but it was a distinction we made. (Personal communication, February 26, 1999)

McIntyre's antipathy towards journalism (or at least to the radio journalism of the time) was increased by the proliferation of news based current affairs radio in the 1960s which had at times produced superficial, second hand accounts of events. Interviews with former Analysis staff revealed a widespread commitment to in-depth use of primary sources whereas some radio journalists were seen as being reliant on secondary sources. Michael Green (an Analysis producer who went to become Controller of Radio 4) expresses the commonly held view that a great deal of journalism at the time was superficial and derivative:

There was a group of people in Broadcasting House who took a very [negative] view of the journalism made in Broadcasting House which they thought was superficial ... this drove them to another pole which said 'how are we going to put into the network something which people will find more challenging, less superficial, more demanding, more authoritative, more first hand?' I would certainly take the view that much of journalism now, as then, is derivative and second hand ..broadcast journalism is essentially a rewrite agency ... and at that time the tide of daily journalism was engulfing people and the end result was a bit unsatisfying for some listeners and they wanted something a bit more challenging. (Personal communication, October 27, 2000)

Analysis was created by people who wanted to challenge the superficial account of the world which they perceived in some contemporary radio journalism. They did this by making the use of primary sources their creed. Interviews, original copies of speeches, parliamentary debates read directly from transcripts, books written by interviewees were all preferred to secondary sources. Despite the near nonexistence of Analysis files for the 1970s at the BBC Written Archive Centre (WAC), 
it is possible to find some circumstantial evidence of commitment to primary sources. This memorandum from George Fischer to Archie Gordon comments on the proposed visit to the USA by Fischer and McIntyre:

There are several 45 - 60 minute (or even longer) conversations in that visit to the U.S. Speakers we have been in touch with or have been trying to get are L.B.Johnson, Dean Rusk, George Ball and Ralph Nader. I strongly recommend that Ian should be given the opportunity to spend some time at the UN headquarters to collect and record material for the forthcoming UN programs. ... McIntyre's visit to the UN headquarters would make a very substantial difference to the content and the authenticity of the UN programs. (George Fischer to Archie Gordon, undated 1970)

The creators of Analysis were united by affinity, shared experiences in radio and what are characterized here as conservative, or Reithian, broadcasting values. They had one further belief which contributed to their solidarity, a commitment to radio itself. The triumph of television over radio in the 1950s and 1960s (Crisell, 2001) may have moved Mansell and Gillard to compromise and create popular but secondary radio but some radio producers clearly wanted to assert radio’s superiority. Howard Newby (who became Managing Director of BBC Radio) described one of the qualities he admire in McIntyre, “... he liked McIntyre’s ‘deep commitment to radio broadcasting, and his belief, unlike most of his contemporaries, that it really did have an important part to play in the future " (Carpenter, 1996, p.298). Analysis was extraordinarily ambitious. McIntyre and Fischer in particular were driven by their commitment to getting the most distinguished contributors and basing their programs on the most rigorous research. This 'driven' quality to their work perhaps signalled not only an attempt to outdo the much disliked journalistic competition but also to show superiority over television.

Returning to the details of the birth of Analysis, the program that Whitby and others created was weekly and forty-five minutes long. Each edition dealt with one subject and was broadcast on Friday evening with a repeat on Sundays. The subjects covered included national and international themes and political and economic issues were dominant. The form and style of Analysis was exceptional only for its 
simplicity. There were three main variations in the series; a pre-recorded documentary featuring a scripted presentation and the voices of contributors; a live discussion chaired by the presenter and a one-to-one interview usually with a leading British politician. There were almost no variations from these three program formats with the exception of the occasional combination of documentary and follow up studio discussion. In addition, Analysis was purely a speech program, there was rarely any 'actuality'. Analysis was similar to its forerunners in Radio 3 and the Third Programme such as those made by McIntyre and Fischer in the 1960s. The pace of Analysis contrasted with that of programs like The World at One and Today. The 1974 BBC Handbook talks of its 'more leisurely, considered and reflective' style and the one-to-one interviews were referred to as 'conversations'.

The newly appointed Controller, Radio, Tony Whitby wrote a series of articles about the new schedule on Radio 4 in the Radio Times. His mission for Analysis is particularly revealing:

We've got to accustom the audience to the fact there will be tougher programmes in the new Radio 4 than there were in the old one. Between 9 and 10 in the evening, the fare will tend to be more thoughtful, tougher in intellectual terms, and will include material previously thought of as Third Programme.

Let's take an example. Analysis is the new current affairs documentary which I shall put on Friday nights at 9.15. Now my brief for the programme is - to be true to your subject. Say what you want to say, say it clearly, lucidly, in a form that a reasonably intelligent, reasonably well informed person can understand. Aim at excellence, and at nothing else. There's no word about the size of the audience in that brief. If it gets a low audience figure, I shall not be surprised. So the programme is protected to that extent. If it gets a larger audience I shall be delighted. There is no reason why it shouldn't - anybody can tune in to the radio at 9.15 on a Friday night. (Radio Times, April 1970)

Whitby makes explicit here the Radio 4 inheritance from Radio 3. Analysis is described as an example of this 'tougher' and 'more thoughtful' program. The suggestion that 'excellence' is more important than any consideration of the audience is typically Reithian. The rather throw away remark that 'anybody' could listen is 
perhaps a little disingenuous. A rather more realistic view of the audience is provided by Greville Havenhand who was both producer and the series editor in the mid 1970s:

... you were aiming at an elite audience ... you were actually aiming at opinion formers, and because the average Joe Public wasn't going to turn on to a program like that at eight o'clock on a Thursday evening for three quarters of an hour .. you could have made it a popular program but it wouldn't have been popular ... you were aiming at a certain intellectual level that would appeal to these people. (Greville Havenhand, personal communication, October 30, 1998)

The 'perceived audience' is easy to discern from comments such as the one above; well educated and well informed and possibly including ‘opinion formers’ or members of elite groups. Because the audience was felt by producers and presenters to be small and knowledgeable, this facilitated the program's intimacy and informality which can be detected in existing recordings. Contributors were told who the audience was and encouraged to speak more freely as a result:

When you got someone for the programme you actually explained what the audience was and said this is not a mass audience, this is an opinion former's audience ... they had their guard down and they also didn't talk down. (Greville Havenhand, personal communication, October 30, 1998)

Encouraged to believe that they were talking to their peers, elite contributors may have been less guarded than for a television current affairs programme like Panorama with its considerably larger audiences. The effect of this on programs is seen in the tendency to assume knowledge and understanding of the wide-ranging political, historical and cultural (especially literary) references which are made in most editions of Analysis.

Another distinctive feature of the programme was the choice of contributors. Analysis, unsurprisingly for such an ambitious programme, always aimed for the most prestigious contributors possible. One-to-one interviews were normally reserved for prime ministers, the chancellor of the exchequer and foreign heads of state. Other 
contributors were used as experts and academics from Oxford, Cambridge and London universities featured prominently as did a wide range of prominent politicians, trade unionists, diplomats, industrialists and others. As already noted, a distinctive feature of Analysis in the 1970s was its antipathy to journalism. It is no surprise, therefore, that there were no journalists, including specialist correspondents, among contributors at the time (Trethowan, 1984, p. 80).

A feature which Analysis did share with programs like The World at One was in the use of a presenter who acted to 'anchor' the programme. Although very much taken for granted on contemporary current affairs radio and television, the idea of a personality presenter who provided a narrative framework within which varieties of views and argument could be expressed was an innovation of the 1950s. In BBC television news the news reader was seen for the first time in 1955 and they remained anonymous (Briggs, 1995, p.63). The main catalyst for change was the newly formed ITN which borrowed American techniques and used named presenters on camera who also gathered, selected and wrote news. One of their first news presenters, Robin Day proceeded to become a doyen of current affairs presentation and presented both Panorama and Analysis. On radio, William Hardcastle anchored The World at One and The World this Weekend while the colorful Jack de Manio presented Today from 1958 - 1971. Similarly, Richard Dimbleby was a presenter of Panorama from 1955 - 1965. The importance of a respected and professional presenter in current affairs broadcasting is well expressed in Robin Day's appreciation of Dimbleby:

It was Richard's solid presence and personality which won the viewers, kept the viewers, guided the viewers and held the programme together ... No presenter or anchor man has ever achieved his combination of qualities, his rapport with the viewer, his professional aplomb, his mellifluous speech, his sense of occasion, be it glad or gloomy, or his easy natural authority. (Quoted in Lindley, 2002, p. 167)

Dimbleby's 'professionalism' was exactly what Paulu had felt was missing in BBC current affairs in the 1950s (Paulu, 1956, p.121). The lesson had been learned that successful current affairs broadcasting depended on a presenter whose expertise included both knowledge of current affairs and an ability to communicate. 
Communication skills included an ability to summarize ideas and information and also the ability to interview. Both Kumar (Kumar, 1977) and Burns link the development of the presenter with the rise of a more general professionalism in the BBC. Burns describes the dramatic rise in the importance of professionalism in the 1960s:

The word 'professional' had, by 1963, an extraordinarily wide currency throughout the BBC. There were times when it seemed that the word was being credited with almost talismanic quality, representing some absolute principle by which to judge people and achievement. (Burns, 1977, p. 122)

Kumar sees the growth of the 'professional broadcaster' as an inevitable consequence of the heightened importance given to news and current affairs in the 1960s.

Newsreaders became celebrities, so much so that, in Kumar's words, 'the newsreaders, are the news' (Kumar, 1977, p.242). But, he argues, the current affairs broadcasters were more important still. He looked at one week in the life of Robin Day who presented Panorama on the Monday; chaired a radio phone-in on Tuesday; chaired a discussion on media censorship for Radio 3 on the Thursday; presented Analysis on the Friday and chaired a television debate on Sunday (p. 243). This degree of exposure made Day a broadcasting celebrity and added to his stature as a guide and referee in the programs he presented.

Like other current affairs programs, Analysis needed highly competent presenters. Ian McIntyre and Mary Goldring, the two main presenters, had considerable license and influence over the programme. They also employed very different styles of 'broadcast talk' (Cardiff, 1980). McIntyre was the man of letters who crafted elegant and often entertaining editions of Analysis supported by a cast of elite contributors and utilising his own immense capacity to read around the subject and retain large amounts of knowledge. Although a very political animal his style of presentation was beguilingly detached. The mood of his programmes was that of a privileged world; members of the establishment exchanged views which the listener was allowed to overhear. It was also non-confrontational, interviews were 'conversations', there was never any aggression or even irritation on McIntyre’s part, everyone seemed to succumb to his charm. By the mid 1970s the problems of the British economy had 
become more acute. Mary Goldring, already a distinguished journalist specialising in the economy, was a bold but logical choice to succeed McIntyre. She represented a very different tradition and she made the experience of listening to Analysis a very different one. Any tie to the talks tradition of the old Third Programme/ Radio 3 was broken. She brought an urgency to Analysis, which became far less sympathetic to contributors in its mission to explain the crisis of the British economy and the failures of the political class and the trade union movement.

\section{CONCLUSION}

Analysis expressed and resolved the tensions between populism and Reithian elitism in the BBC in the late 1960s and early 1970s. On the one hand the Mansell and Gillard inspired version of current affairs was journalistic and challenged the distinction between news and comment in magazine format news sequences. On the other hand, a non-journalistic tradition of talks inspired current affairs, still surviving in Radio 3 and still championed by a network of men committed to particularly uncompromising standards of research and guest selection as well as an unfashionable belief in radio as a medium.

The BBC was rocked by the response of the cultural establishment to Broadcasting in the Seventies and this was the right moment to create a new and challenging radio current affairs programme. In the rigorousness of its research, the caliber of the contributors and the professionalism of its presenters, Analysis was to demonstrate that, in the words of Ian McIntyre, 'serious things' would indeed be done.

One of the main themes of this article is the specificity of 'current affairs' as expressed in Analysis. Elitism emerges as one of the defining characteristic of the programme, or at least as it existed in the minds of its creators. Elitist because it was anti-populist, or anti radio journalism, in its approach; no journalists would be contributors and 'shoddy', journalistic research techniques were to be scrupulously avoided. Elitist in the selection of contributors, which would include members of a variety of political, academic and other international elites. Elite also in its view of its audience, likely to consist of opinion-formers and people not that dissimilar to the 
speakers themselves. A final aspect of this elitism was its ambitious affirmation of radio in opposition to the great populist medium of television. Analysis expressed the belief that current affairs exists mainly in the realm of ideas and arguments, not in the world of spurious visual imagery (Crisell, 2004).

\section{References}

Born,G. 2004). Uncertain Vision: Birt, Dyke and the Reinvention of the BBC. London, UK: Secker and Warburg.

Briggs, A. (1995). The History of Broadcasting in the United Kingdom: Volume VCompetition. Oxford, UK: Oxford University Press.

Burns, T. (1977). The BBC: Public Institution and Private World. London, UK: MacMillan.

Cardiff, D. (1980). The serious and the popular: aspects of the evolution of style in the radio talk, 1928-1939. In R.Collins (Ed.), Media, Culture and Society: A Critical Reader. London, UK: Sage.

Carpenter, H. (1996). The Envy of the World: Fifty Years of the BBC Third Programme and Radio 3. London, UK: Weidenfeld and Nicolson .

Crisell, A. (2002). An Introductory History of British Broadcasting $\left(2^{\text {nd }}\right.$. Ed.) London, UK: Routledge.

Crisell, A. (2004). More than a Music Box. New York: Berghahn.

Fischer, G. (1970). Memorandum. BBC Written Archives, Caversham.

Kumar, K. (1977). Holding the Middle Ground: The BBC, the public and the professional broadcaster. In J.Curran (Ed.) Mass Communication and Society. London, UK: Edward Arnold.

Lindley, R. (2002). Panorama: Fifty Years of Pride and Paranoia. London, UK: Politico's Publishing.

Miall, L. (1994). Inside the BBC: British Broadcasting Characters. London, UK:

Weidenfeld and Nicolson.

Paulu,B. (1956). British Broadcasting: Radio and Television in the United Kingdom. Minneapolis: University of Minnesota Press.

Radio Times. (1970, March 12). Features page. Vol. 186, No. 11, p.10.

Street, S. (2002). A Concise History of British Radio 1922-2002. Tiverton, UK: Kelly Publications.

Trethowan, I. (1984). Split Screen. London, UK: Hamish Hamilton. 